\title{
心電図所見からみた50歳以上の成分献血者とくに頻回献血者の検討
}

\author{
横山 繁樹＼cjkstart芦田美喜子松浦 尚雄 細井 武光 \\ 京都府赤十字血液センター
}

(平成 3 年 5 月 9 日受付)

\section{ELECTROCARDIOGRAPHIC CHANGES OCCURRING IN LONG-TERM PLASMAPHERESES IN OLDER DONORS}

\author{
Shigeki Yokoyama, Mikiko Ashida, Takao Matsuura and Takemitsu Hosoi \\ Kyoto Red Cross Blood Center
}

\begin{abstract}
Over the past six years at Fukuchiyama Red Cross Blood Center electrocardiographic (ECG) changes were studied in 314 older (over 50 -years old) apheresis donors. ECG was examined prior to the first plasmapheresis experience and was compared with ECG recorded at 4 month intervals thereafter. The aim of this study was to ascertain whether plasmaphereses, as it is currently performed, exposes long-term donors to harmful effects. After long-term plasmaphreses, the following findings without clinical symptoms, were observed: slight prolongations of PQ or QT time in 12 cases; left axis deviation in 3 cases; slight left ventricular highvoltage in 3 cases; slight low QRS wave length in 5 cases; and premature ventricular contraction in 2 cases. These findings were in the normal range and were observed mainly in older persons. Comparison of ECGs recorded prior to first plasmapheresis and those observed thereafter showed almost no significant difference. Based upon this 6-year study, we conclude that donors are not at risk of ECG change due to plasmaphereses.
\end{abstract}

はじめに

1986年 4 月より，全国の日赤血液センターにお いて成分献血が導入されてからすでに 5 年経過し た. 導入当初は, 献血者の安全性確保の目的から, 成分採血希望者に対して全員事前に心電図検査が 義務づけられ，その後も心電図検査のもつ意義を 重要視する意見があるものの，一方では全国の総 献血数の $8 \%$ 強が成分献血であり、とくに問題が 見受けられないところから，心電図検査の必要性 について疑義を持つ人も少なくない。そこで今回 われわれは心電図上で変化を起こしやすいと予想 される50歳以上の頻回な血浆成分献血者を対象に して, 経年的に心電図上の変化に検討を加えたと ころ，とくに頻回な成分献血に由来すると疑われ るような所見は現在のところまったく認められな かったので, その詳細を報告するとともに高蹂者 に打ける成分採血施行時の注意点に言及した。

\section{対象症例及び方法}

京都府福知山血液センターにおいて，1985年以 降1990年迄の 6 年間に 50 歳以上の成分献血者（全 例が多血小板血浆または乏血小板血浆採血, 使用 自動装置はHaemonetics社のV50, PCS, Ultralight-PCS）でかつ 2 回以上の経験者は男性 258 名, 女性56名計 314 名あり, そのらち年 4 回以 上かつ 2 年以上継続して成分採血を行ってきた献 血者（頻回献血者之略）は, 男性50名, 女性 5 名 計55名（内 3 年以上継続例が男性 42 名女性 4 名） であった. 上記の314名については全例, 初回施行 前, その後年間 $2 \sim 4$ 回心電図が記録されており, それらの心電図を循環器疾患専門医として長年臨 床に従事してきた医師が解析を行った。な敃解析 にあたっては, 年齢, 性別, 体重, 問診, 検診結 果等を考慮した診断だけではなく, $\mathrm{P}$ 波, $\mathrm{PQ}, \mathrm{QT}$ 時間, $\mathrm{QRS}$ の波高, 電気軸, $\mathrm{T}$ 波等の所見を可能 なかぎり詳細に検討を加えた。 
具体的な検討方法としてはまず50歳以上の初回 施行前の心電図所見について，その所見と頻度を 調べ，ついで各献血者別にその後経年的に成分採 血施行前に記録した心電図所見を初回施行前の所 見と対比させることにより得られた結果を，成分 採血施行回数別に分けて検討を行った. さらに, 初回施行前要注意と判断された有所見者でかつ頻 回な成分献血者である 7 名については，最近の心 電図所見と成分採血回数について検討を加えた。

\section{成 績}

（1）初回成分採血施行前の心電図所見

今回の検討対象となった計314名の50歳以上の 成分献血者は全例，厚生省の採血基準に合致し，

表 1 初回施行前の心電図所見

\begin{tabular}{|c|c|}
\hline 所 見 & 例 数 (\%) \\
\hline 正常範囲 & $260 \quad(83.0)$ \\
\hline 軸偏位（左軸，右軸） & $16(5.1)$ \\
\hline 洞性不整脈, 洞性徐脈 & $11(3.4)$ \\
\hline I 度房室ブロック & $2(0.6)$ \\
\hline 心室性期外収縮（散発性） & $5 \quad(1.7)$ \\
\hline 完全右脚ブロック & $2(0.6)$ \\
\hline 不完全右脚ブロック & $7(2.2)$ \\
\hline 心筋梗塞（疑い） & $2(0.6)$ \\
\hline 左室肥大 & $0\left(\begin{array}{ll}0\end{array}\right)$ \\
\hline 左房負荷 & $0\left(\begin{array}{ll}0\end{array}\right)$ \\
\hline その他（右室伝導遅延等） & $9(2.8)$ \\
\hline
\end{tabular}

（）内は対象総数に占める比率
さらに問診，検診結果から成分採血可能とされた 人である，したがって成分採血施行前の心電図所 見は表 1 に示すごとく，83\%が正常範囲であり， 心筋梗塞の疑われた 2 例を除けば，全て病的意義 のある心電図所見ではなかった。ただ，軸偏位の みの有所見者が16例 (5.1\%) 認められたが，これ は高齢者といらことで特に問題にはしなかった。

(2) 成分献血経験者の最新心電図の所見

上記の 314 名の成分献血者について, 最新の心電 図所見を対比させたが，初回施行前の有所見者に は変化がなく，したがって初回施行前の正常範囲 内の献血者に認められた所見を，成分採血施行回 数別に分けて表 2 に示した。初回施行前に比べ $\mathrm{PQ}$ 時間が若干延長した例が 9 例(男性 7 例，女性 2 例)，QT 時間がやや延長した例が 3 例（男性 2 例, 女性 1 例), QRS 波高がやや低下した例が 5 例 (全例男性)，また左軸偏位になったものが 3 例(男 性 2 例，女性 1 例）認められた。一方表 2 の結果 からみれば成分献血施行回数が増えるにつれ変化 した例が増加しているよらに見えるが，上記の所 見は心電図上の診断でいずれも正常範囲内の所見 であった。

ただし左室肥大を疑われる所見を示した男性 3 例と散発性の心室性期外収縮を示した男性 2 例に ついては，現在毎回心電図を取りながら注意しつ つ成分採血を続行している。このうち65歳の 1 例

表 2 初回施行前心電図と最近の心電図との対比

\begin{tabular}{|c|c|c|c|c|c|c|c|}
\hline \multirow{2}{*}{$\begin{array}{l}\text { 成分献血 } \\
\text { 施行回数 } \\
\text { (回) }\end{array}$} & \multirow{2}{*}{$\begin{array}{c}\text { ドナー数 } \\
\text { (名) }\end{array}$} & \multicolumn{6}{|c|}{ 最近の心電図所見 } \\
\hline & & $P Q$ 延長 & QT 延長 & QRS 波高低下 & 左軸偏位 & LVH(軽度)* & VPC (散発) $)^{* *}$ \\
\hline 10以下 & 238 & 1 & 1 & & & 2 & \\
\hline $10-19$ & 31 & 2 & 2 & 1 & 1 & 1 & \\
\hline $20-29$ & 12 & & & 2 & & & \\
\hline $30-39$ & 10 & 2 & & & 1 & & \\
\hline $40-49$ & 8 & 2 & & 1 & 1 & & \\
\hline $50-59$ & 8 & & & & & & \\
\hline $60-69$ & 4 & 1 & & 1 & & & \\
\hline 70 以上 & 3 & 1 & & & & & 2 \\
\hline 計 & 314 & 9 & 3 & 5 & 3 & 3 & 2 \\
\hline
\end{tabular}

${ }^{*} \mathrm{LVH}$ : Left ventricular highvoltage.

${ }^{* *} \mathrm{VPC}$ : Ventricular premature contraction. 
阳利6 3 年6月11日

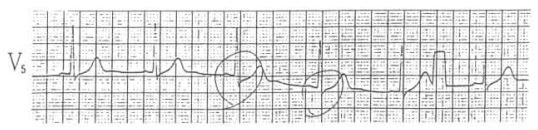

平成元年3月4日

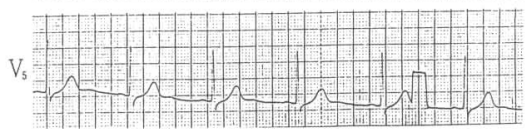

平成2 2 年6月23日

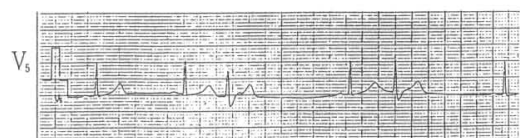

平成2 2 年7月14日

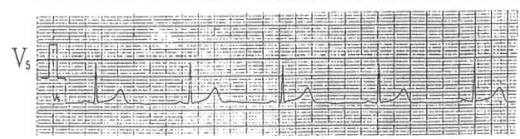

図 1 K.N (65歳) 心電図変化

については図 1 に示すごとく 1 時期 2 段脈を示し たものの最近では全く消失している。

表 2 の 万ち頻回献血者は施行回数 10 回以上の 76 例中55例であり，また施行回数 30 回以上の 33 例は 全例 3 年以上の頻回献血者であるが，らち12例 （36\%）に心電図所見上変化がでてきたことにな り，一見高率にはみ党るものの，この 12 例は全例 現在55歳以上であること，また所見の内容が高齢 化に伴う所見であることを考慮すれば，頻回な成 分献血がとくに心電図上有意義の変化をきたしや すいという結論にはならないと判断された。

（3）初回施行時に所見を認めた頻回献血者 洞性不整脈（16例），右室伝導遅延（9例）につ いては，所見そのものに意義がなく，したがって 最大69回（平均22回）の成分採血が施行されてき
たが最近の心電図は全例変化がなく，また他の所 見が附加されていることもなかった。あたー $30^{\circ} \mathrm{C}$ 以上の左軸偏位, $+110^{\circ}$ 以上の右軸偏位 16 例につ いても，偏位度には変化がなかった。 $\mathrm{PQ}$ 時間 $0.22,0.26$ 秒の 1 度房室ブロックの 2 例は共に25 回を超す回数にもかかわらず，PQ 時間の延長は 認めていない。散発性心室性期外収縮の 5 例でも 変化はなく, らち 2 例では最近の心電図で当初認 められた期外收縮が消失していた。气の他初回施 行時からわれわれがとくに注意を払ってきた 7 例 についてはその詳細を表 3 に示したが，いずれも 最近の心電図所見では初回施行前の所見と比べ まったく変化がなく，健康状態も良好でとくに頻 回な成分採血の影響は認められていない。

（4）成分献血中止例

頻回成分献血者 55 例中, 年齢が 65 歳になり中止 した者が 4 例，その他病気で中止した者が 2 例計 6 例あったが，有病例はいずれも心臓疾患とは無 関係の疾患であり，少なくとも頻回な成分採血が 関係して成分献血をやめた例は現在まで認めてい ない.

\section{考察}

1983年 Huestis ${ }^{1}{ }^{\text {が}}$, 治療的プラプマフェレーシ スに起因して死亡した42例について検討を加えた ところ，らち12例が心機能障害であったという報 告以降は, 治療的プラスマフェレーシスには心電 図モニターの必要性が強調されてきた。わが国に 抒いても Komatsu ら ${ }^{2)}$ が291例のドナー・プラズ

表 3 初回有所見者に和ける頻回な成分献血施行ドナーの心電図変化

\begin{tabular}{|c|c|c|c|c|c|c|}
\hline No. & ドナー名 & 性 & 年齢 & 初回時所見 & 成分採血回数 & 最近の所見 \\
\hline 1 & A. N. & 男 & 62 & 陰性 ST & 51 & 変化なし* \\
\hline 2 & T. I. & 女 & 60 & II, III, a $\mathrm{VF}_{\mathrm{F}}$ の $\mathrm{ST}$ 上昇 & 14 & 変化なし \\
\hline 3 & H. G. & 男 & 56 & 完全右脚ブロック & 14 & 変化なし \\
\hline 4 & I. T. & 男 & 55 & 完全右脚プロック & 20 & 変化なし \\
\hline 5 & E. M. & 男 & 63 & $\begin{array}{c}\text { 不完全右脚ブロック } \\
\text { +右軸偏位 }\end{array}$ & 29 & 変化なし \\
\hline 6 & K. O. & 男 & 55 & $\begin{aligned} & \text { 心室性期外収縮 } \\
+ & 1 \text { 度宣至ブロック }\end{aligned}$ & 12 & 変化なし \\
\hline 7 & M. S. & 男 & 51 & $\begin{array}{c}\text { 左軸偏位 } \\
+ \text { 左室肥大 }(\text { 軽度) }\end{array}$ & 20 & 変化なし \\
\hline
\end{tabular}

*変化なしは, 初回心電図と比べ所見に変化が認められていないことをさす。 
マフェレーシス（血小板と顆粒球採取）で10\%の 29例に頻脈, 徐脈, 心室性期外収縮, 右脚ブロッ ク， ST 上昇や T 波の陰性化等の所見を認め，ド ナー・プラズマフェレーシスといえどもその施行 には細心の注意を要することを報告している。こ のよらな報告の影響もあって，1986年 4 月わが国 の血液センターに成分献血が導入されてから以降 の $2 \sim 3$ 年間は, 成分献血は危険度の高いものと 受け取られ，その普及は大幅に遅れたと言える。 事実大部分の血液センターに打いては事前の心電 図検査（ミネソタコードによる診断）で少しでも 所見があれば成分採血は施行しないという結果が 報告3されている。しかしわれわれは血液セン ターで施行される成分採血は血浆と血小板採取に 限られて扣り，したがって事前に献血者の選択と 採血中のドナーの観察に注意すれば血液センター に打ける成分採血は安全性が極めて高く，また血 浆成分採血では採血中心電図モニターは不要であ ることを報告4してきた。とくに近年血液凝固VIII, IX因子の原料血浆を国内の献血で賄らといら方針 が出されてからは，血浆成分献血がオープン形式 や，通常の移動採血車内でも施行されるようにな $\eta^{5)}$ ，心電図検査は可能なかぎり省略したいとい う希望が血液センター側にある。

そこで今回われわれは心電図に変化をきたしゃ すい50歳以上の成分献血者を対象にして，成分採 血が心電図所見に及ぼす影響の有無を調べてみ た。すでにわれわれは50歳以上の高龄者における 頻回な成分採血が免疫グロブリンに及ぼす影響を 調べてみたが, IgG, IgM が若干低下するものの， その測定値は正常範囲に留まること，またその低 下度に年龄的な差異は認められないことを報告6) してきた。今回の心電図からの検討についても， 表 1 , 表 2 , 表 3 の結果から見て，50歳以上の頻 回な成分献血者では，成分献血に起因したと考え られるよらな心電図上の変化は認められなかっ た。たしかに $\mathrm{PQ}$ 時間 $\mathrm{QT}$ 時間の延長, $\mathrm{QRS}$ の波 高の低下や電気軸の左軸偏位等の所見が初回無所 見者の6.3\% (20例) に認められたものの，これら はいずれも高柃者にみられる老人性変化であっ て，成分献血に起因したものとは考えられなかっ
た.

Komatsu $5^{2)}$ の採血中の心電図変化では血管迷 走神経反射（VVR と略）に由来する徐脈，ST の 変化が含まれているが，採血中の VVR は成分採 血に特有のものではないこと，またVVRは一過 性の反応であり回復が早いことからみて，採血中 ドナーをリラックスさせ，VVRを惹起しないよ らな配慮（ビデオを見せるとか，音楽を聞かせる 等）を行劣ば，特に術中の心電図モニターは不要 であると判断している．今回の検討対象にした50 歳以上の献血者ではVVR は 3 例（VVR 疑い 2 例，I 度 1 例）しか認められていないこともあっ て，VVR 発生時の心電図の検討はなされていな いが，いずれも特別の処置をすることなく回復し て扣り，心電図モニターの必要性は認められな かった。

その他今回のわれわれの検討からすれば，あら かじめ事前に軽度の心筋障害や左心肥大，良性の 完全右脚ブロック等の所見が認められていても， 採血中ドナーの観察に細心の注意を支払えばたと 光頻回な血浆成分採血を施行しても心電図に病的 意義のある変化を来すことはないのではないかと の結果が得られた。

\section{結 論}

50 歳以上の成分献血者 314 例, とくに年間 4 回以 上 2 年以上継続して成分献血を施行してきた 55 例 を中心に，頻回な成分採血が心電図所見に及ぼす 影響を調べた。

（1）初回有所見者に頻回な成分採血を施行して も，心電図上変化はなく，新たに病的な所見は現 在まで 1 件も認められていない.

（2）初回無所見者であっても $6 \%$ \%Q 時間, QT 時間の延長, QRS 波高低下, 左軸偏位を認め たものの，その程度は正常範囲内の変化であり， またその変化も高齢化に伴う老人性変化と推察さ れた。

（3）したがって事前心電図上の所見の有無にか かわらず，それが日赤業務規定の献血者選択の項 で定められた所見であり, また採血中, 後のドナー の観察に細心の注意を支払えば頻回な成分献血で も安全性は極めて高いとの結論が得られた。 
本論文の要旨は第34回日本輸血学会近畿支部総会におい て報告した。

\section{文献}

1) Huestis, D.W.: Mortality in therapeutic haemapheresis (letter). Lancet, I : 1043, 1983.

2) Komatsu, F., et al.: Abnormal electrocardiographic findings in apheresis donors. Transfusion, $28: 371-374,1988$.

3）横山繁樹：成分献血不適格とされた心電図の検
討. 血液事業, $11: 265-272,1988$.

4）横山繁樹, 他：心電図からみた血液成分献血者の 適否についての検討. 血液事業, $10: 31-36,1987$.

5）横山繁樹：移動出張成分採血における血漿採取. 輸血研究の進歩 (関口定美 編), p66-79, 富士書 院, 1990.

6）芦田美喜子, 他：60 歳以上の成分献血者における 頻回な採血漿が免疫グロブリンに及ぼす影響。第 38 回日本輸血学会総会抄録集, p. $329,1990$. 